\section{Maternal transfer of HCV}

SIR - Hepatitis C virus (HCV) is the main causative agent for sporadic as well as parenteral cases of non-A, non-B hepatitis $^{1,2}$. It is not clear, however, whether the virus can be transmitted other than by blood transfusion. Motherto-child transmission, which is the main route for the hepatitis $B$ virus to establish new carrier states, has not been

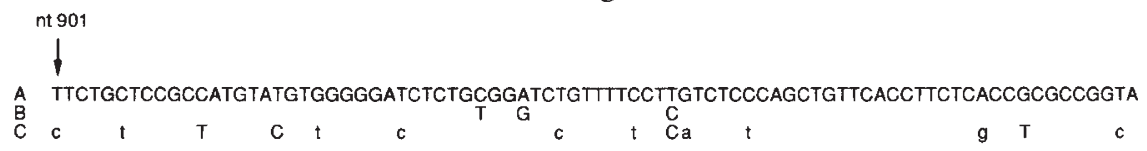
$\begin{array}{llllll}\text { A } & \text { CGAGACGGTACAAGACTGCAATTGCTCGCTCTATCCCGGCCATGTATCAGGTCACCGCATGGCTTGGGATATGATGATGAAC } \\ \mathrm{B} & \mathrm{T} \mathrm{C} & \mathrm{C} & \mathrm{C} & \mathrm{C} & \mathrm{C}\end{array}$ Nucleotide sequences of a part of the HCV genome encoding the envelope protein. A, Complementary DNA derived from the baby and the mother; $B$, cDNA derived from the grandmother; C, cDNAs derived from four different $\mathrm{HCV}$ clones ${ }^{5-8}$. Only nucleotides different from $A$ are shown in $B$ and $C$. In $C$, capital letters indicate all four clones have the same nucleotides but different from $A$, lower-case letters show that at least one clone has indicated nucleotides different from $A$.

confirmed by existing anti-HCV assays. Among children under the age of 10 , the prevalence of anti-C100, an assay detecting antibody to molecularly expressed $\mathrm{HCV}$ non-structural protein in yeast ${ }^{2}$, is significantly $l_{0}{ }^{3}$. Such seroepidemiological findings even led to the notion that mother-to-child transmission of $\mathrm{HCV}$ is unlikely. If this is the case, it is unclear how HCV can persist in the community and maintain high carrier rates throughout the world $(0.2-2.6 \%)$.

Here, we report a family in which $\mathrm{HCV}$ was transmitted from mother to child through two generations. A female baby developed acute, resolving type of hepatitis $\mathrm{C}$ and the diagnosis was confirmed by the anti-C100 assay. Although both her mother and grandmother were negative for anti-C100, they were considered to be healthy HCV carriers as they had the antibody against an HCV nucleocapsid antigen (p22) which was expressed in insect cells by a recombinant baculovirus ${ }^{4}$. Amplified $\mathrm{HCV}$ complementary DNA fragments were detected in the sera from the baby, the mother and the grandmother but shown by the polymerase chain reaction (PCR) method not to come from the father.

The nucleotide sequence of part of the HCV genome encoding the viral envelope protein was determined and analysed (see figure). The difference in the nucleotide sequences of this region among four different HCV cDNA clones reported in Japan is $16.3 \%$ (refs 5-8). We find, however, that the sequences of 165 nucleotides (901-1065) in the baby and the mother were completely identical, suggesting strongly that the $\mathrm{HCV}$ in the baby was derived directly from the mother. Six nucleotides $(3.6 \%)$ were different from those of the grandmother.
However, five of the six nucleotides were on the third letter of the codons, Such close similarity among HCV cDNAs in the family is explained if the grandmother transmitted the $\mathrm{HCV}$ to the mother at the mother's birth 27 years ago. This possibility is likely because the grandmother received a blood transfusion 37 years ago and developed acute non-A, non-B hepatitis afterwards. Abnormal liver function was indicated when she delivered her first baby (the mother referred to above). In summary, as far as the region of the HCV genome we examined is concerned, the cDNA fragment from the baby is identical to that from the mother and more closely related to that from the grandmother than those from other Japanese isolates.

\section{Neurovirulence factor}

SIR - The ICP34.5 protein of herpes simplex virus type 1 (HSV-1) and its HSV-2 counterpart are potent neurovirulence factors ${ }^{1,2}$ : viruses defective in resulting in only one amino-acid change. MyD116.

these genes require a $10^{5}$-fold increase in dose over wild-type to kill mice by intracerebral inoculation. We have found that the two protein sequences show most similarity $(83 \%$ identical residues) in a 63-residue section near their carboxy termini. We have discovered that a mouse protein (MyD116; ref.3) possesses a striking homologue of this 63-residue domain (see figure). Other parts of MyD116 are dissimilar to the HSV proteins, except for an acidic locus in each. No other database entries are similar to ICP34.5 or MyD116.

MyD116 is predicted from the sequence of a transcript expressed immediately during differentiation of a
These results indicate that the motherto-child transmission of $\mathrm{HCV}$ does occur. The baby's hepatitis was selflimiting and transient. HCV infection in the mother and the grandmother was confirmed only by anti-p22 assay and by detailed analysis of the PCR products. It is possible that $\mathrm{HCV}$ transmitted from mother to child could result in transient or even subclinical hepatitis in babies which could persist for long periods of time. This may also explain the reason why a high prevalence of HCV infection among communities is maintained.

Department of Enteroviruses,

National Institute of Health,

Tokyo 141, Japan

Department of Pediatrics,

Ashigarakami Hospital,

Kanagawa 258, Japan

T. UNAYAMA

K. TAKAHASHI

Laboratory of Molecular Genetics

Institute of Medical Science,

Tokyo 108, Japan

1. Choo, Q.-L. et al. Science 244, 359-362 (1989)

2. Kuo, G. et al. Science 244, 362-364 (1989).

3. Watanabe, J. et al. Vox Sanguis 59, 86-88 (1990).

4. Chiba, J. et al. Proc. natn. Acad. Sci. U.S.A. 88 4641-4645 (1991)

5. Takeuchi, K. et al. J. gen. Virol. 71, 3027-3033 (1990).

6. Okamoto, H. et al. Jap. J. exp. Med. 60. 167-177 (1990).

Kato, N. et al. Proc. natn. Acad. Sci. U.S.A. 87 9524-9528 (1990)

8. Takamizawa, A et al. J. Virol. 65, 1105-1113 (1991)

myeloid leukaemic cell line induced by interleukin-6, and also in bone marrow ${ }^{4}$; it probably acts directly in controlling cell state, perhaps as a transcription factor or a modifier of cytoskeletal structure. ICP34.5 might act as a mimic or an antagonist of a MyD116-related cellular protein in infected brain cells. The re-

\section{Y. INOUE \\ T. MIYAMURA}

HSV-1 193 VRFSPHVRVRHLVVWASAARLARRGSWARERADRARFRRRVAEAEAVIGPCLGPEARARALAR HSV-2 166 VCFSPRVQVRHLVAWETAARLARRGSWARERADRDRFRRRVAAAEAVIGPCLEPEARARARAR MYD116 549 VHFAEKVTVHFLAVWAGPAQAARRGPWEQFARDRSRFARRIAQAEEKLGPYLTPDSRARAWAR

HSV Con V-FSP-V-VRHLV-W--AARLARRGSWARERADR-RFRRRVA-AEAVIGPCL-PEARARA-AR Total Con V-E---V-V--L--W---A--ARRG-W-----DR-RF-RR-A-AE---GP-I-P--RARA-AR Comparison of amino-acid sequences of the 63-residue similar domains of HSV-1, HSV-2 and markable conservation of one region within otherwise distinct proteins from diverse sources suggests a functional module, other examples of which may emerge.

MRC Virology Unit,

Institute of Virology,

University of Glasgow,

Glasgow G11 5JR, UK

1. Chou, J., Kern, E. R., Whitley, R. J. \& Roizman, B. Science 250, 1262-1265 (1990).

Taha, M. Y., Clements, G. B. \& Brown, S. M. J. gen. Virol. 70, 3073-3078 (1989).

3. Lord, K. A., Hoffman-Liebermann, B. \& Liebermann, D. A. Nucleic Acids Res. 18, 2823 (1990).

4. Lord, K. A., Hoffman-Liebermann, B. \& Liebermann, D. A Oncogene 5, 387-396 (1990). 